\title{
To drive or to use the bus? An exploratory study of older people in Malta
}

\author{
Deborah Mifsud $^{\mathrm{a}, *}$, Maria Attard ${ }^{\mathrm{b}}$, Stephen Ison ${ }^{\mathrm{c}}$ \\ a Department of Geography, Faculty of Arts, ICCSD Research Offices, Porta Cabins Block B, Car Park 6, University of Malta, Msida MSD2080, Malta \\ b Department of Geography, Faculty of Arts, OH132, University of Malta, Msida MSD2080, Malta \\ c Transport Studies Group, School of Architecture, Building and Civil Engineering, Loughborough University, Ashby Road, Loughborough, Leicestershire LE113TU, UK
}

\section{A R T I C L E I N F O}

\section{Keywords:}

Older people

Mode choice

Mobility determinants

Malta

\begin{abstract}
A B S T R A C T
Older adults are becoming a larger portion of the world's population, and as a result, more attention is being given to their mobility and travel behaviour. Such studies are however lacking in certain contexts like in Malta, an island state in the Mediterranean Sea. Malta is facing a concurrent high population density, high motorisation rate and an ageing population. Nevertheless, older people's mobility is not adequately considered in transport policy. The aim of this paper is to have an exploratory understanding of mode choice in later life in Malta, and understand the key determinants that affect older people's decision to drive or to use the bus. Using descriptive statistics and two regression models, this paper shows how in Malta older males drive significantly more than females, and the latter use more public transport. As age increases, the percentage of drivers declines for both genders. On the other hand, whilst for females public transport use also declined with age, the pattern of usage amongst males fluctuated. The data also showed that public transport was mostly used by non-driving older people who could potentially be captive bus users. The determinants that predicted whether older people drove or not were (i) gender, (ii) age, (iii) their occupation status, and (iv) the presence of an assistive device. The significant predictors for older people's public transport use were (i) the number of cars available in the household, (ii) age, (iii) the district where they lived, (iv) their occupation status, (v) their participation in social activities and (vi) the presence of personal assistance. The two models revealed different predictors for mode choice however there were also several similarities. The paper concludes with a discussion, highlighting the importance and relevance of the results to transport policy-makers. It also provides suggestions for further research to examine older people's mobility and travel behaviour.
\end{abstract}

\section{Introduction}

Social changes are amongst the key factors that affect mobility, and one such phenomenon which is receiving increasing attention is population ageing (Rudinger et al., 2006). Between 2015 and 2030, people over the age of 60 are expected to increase from 901 million to 1.4 billion (UN, 2015). This has implications on different sectors of society, including transport. Travel behaviour of older people was analysed from different perspectives such as trip making, trip distance, travel patterns, trip chaining and transport deficiencies (e.g. Golob and Hensher, 2007; Kim, 2011; Mercado and Páez, 2009; O'Fallon and Sullivan, 2009; Páez et al., 2007). One factor which can influence such factors is mode choice, which is the focus of this paper.

Due to such an increase in ageing communities, it is important to study travel behaviour in later life because good mobility is linked with a good quality of life for older people (Musselwhite and Haddad, 2010). However, the natural process of ageing is associated with different physiological changes that can have significant consequences on mobility (Shrestha et al., 2016). Actually, older people are usually considered as one of the transport-disadvantaged groups in society (Lucas et al., 2001). They can even suffer from social exclusion due to various difficulties associated with travelling to access services, particularly for non-drivers (Engels and Liu, 2011; Shergold and Parkhurst, 2012). Such situations are even worse when public transport does not adequately cater for their needs (Engels and Liu, 2011). Given such limitations, when compared with younger individuals, the overall mobility of older people is lower than that of younger individuals (Collia et al., 2003; Schwanen et al., 2001).

Despite this, travel in later life has increased significantly throughout the years. Older people have more active lifestyles and one key reason for this is the increasing number of older drivers (Rosenbloom, 2001). The importance of car use for older people is also evident from the negative implications associated with driving cessation. Older people who stop driving can suffer from a lower quality of life and health problems (Marottoli et al., 2000). Nonetheless, higher car use can also reflect negatively on the health status of older people

\footnotetext{
* Corresponding author.

E-mail addresses: deborah.mifsud@um.edu.mt (D. Mifsud), maria.attard@um.edu.mt (M. Attard), s.g.ison@lboro.ac.uk (S. Ison).
} 
due to the lack of physical movement (Kemperman and Timmermans, 2014). Moreover, it is widely acknowledged that the increase in car use has negative implications on the environment and is a significant and growing contributor to climate change (Gössling et al., 2016). Therefore, given the overall increase in the numbers of drivers, it is also important to motivate people to shift away from their car and use public transport for environmental reasons. This shows the importance for policy-makers to understand mode choice and its determinants so as to work towards a sustainable balance in the modes of transport that older people use.

An understanding of the context is critical to truly understand the factors which encourage older people to choose specific modes of transport. In contrast to the mounting studies dealing with older people's mobility, such knowledge is still lacking in certain contexts, particularly in island states like Malta. The main aim of this paper is to have an exploratory understanding of mode choice in later life in Malta, and understand the key determinants that affect older people's decision to drive and to use the bus. This will complement international efforts which are working to enhance knowledge for policy-makers to determine the best policies required to meet the mobility needs of older people.

This paper consists of six sections. This introduction is followed by a literature review focusing specifically on mode choice of older people and its determinants. Section three describes the case study of the research, and section four discusses the research methods. This is followed by the presentation of results in section five and a discussion in section six.

\section{Mode choice in later life: private car vs public transport}

Older people are the fastest growing segment of the driving population (Banister and Bowling, 2004). Studies in different contexts showed that the car is the main mode of transport that older people use for their travel (e.g. Collia et al., 2003; Mercado and Newbold, 2009; Schmöcker et al., 2008, Schwanen et al., 2001). This means that older people are making more trips per day and driving longer distances. For example, a driving licence and car access had a positive impact on trip frequencies of older people in Canada (Páez et al., 2007). In a study in Denmark, Norway and Sweden, Hjorthol et al. (2010) also showed that older people with no driving licence made fewer trips. Nonetheless, given the physiological changes associated with ageing, older people can face multiple obstacles when driving, particularly in dual-task situations (Leversen et al., 2013). Some common difficulties that they encounter are when turning (particularly towards the left), when judging the safety of a gap in conflicting traffic movements, when driving in intersections, when having to change high-speed lanes, when reading certain street names and signs, when following road markings and when driving in bad weather (Lyman et al., 2001; Chandraratna and Stamatiadis, 2003; Mayhew et al., 2006; Gelau et al., 2011; DaCoTA, 2012). Common ageing restrictions namely sensory, cognitive and medical problems usually predict the driving ability in later life (Anstey et al., 2005). Such health limitations also affect road safety of both the older people and of other vulnerable road users (Rogé et al., 2014).

Public transport is essential to keep people independent and mobile as they get older. This is because a lack of access to transport leads to inequities (Engels and Liu, 2011). Despite this, public transport use amongst older people can be quite low (Collia et al., 2003; Rye and Scotney, 2004). Older people may prefer the car even when public transport works efficiently due to the convenience associated with private transport (Li et al., 2012). Driving could also be a reflection of a lack in alternative options (Rosenbloom, 2001). However, there are also the public transport "captive users" (Beimborn et al., 2003) who are restricted to use public transport due to different reasons as lower income levels (Kim and Ulfarsson, 2004). Older public transport users can face several problems which discourage them from using such mode of transport (Fiedler, 2007). As a result, there are different requirements that public transport has to meet in order to cater for the needs of older people. These are usually related to affordability, availability, accessibility and acceptability (Shrestha et al., 2016). For example, modern technologies that convey public transport information may not always be catering for the mobility needs of older people (Hounsell et al., 2016). Other common problems are related to access and accessibility issues, travel time, lack of comfort, lack of reliability and boarding constraints (Davey, 2007; Fiedler, 2007; Hess, 2009; Wrestrand et al., 2009; Zeitler et al., 2012; Mifsud and Attard, 2013; Sundling et al., 2015). In Malta, Mifsud and Attard (2013) showed that $72 \%$ of the older bus users encountered some sort of barrier when using public transport. This means that, in order to have a wider picture of how older people travel, it is also important to understand the determinants for public transport use. For example, Hess (2009) showed that in a pooled-analysis for Buffalo and San José (United States), living in single-households tended to positively affect public transport usage for older people. Thus, the provision of attractive and accessible public transport services is a crucial policy for addressing the transport needs of older people (Shrestha et al., 2016).

This means that although the mobility of older people is increasing, they still remain a vulnerable and disadvantaged group in the transport environment. It is thus important for transport policy-makers to better understand the determinants of how they travel in order to provide them with more independent mobility.

\subsection{Determinants of mode choice for older people}

The travel behaviour of old people can be quite complex (Hildebrand, 2003), and the multilevel conceptual ecological model can help to explain its determinants. Such a model, originating from the public health literature (Sallis et al., 2008) states that behaviour is affected by individual, social/cultural and environmental factors. Individual factors refer to the individual's skill to act and participate in the desired activities. Social and cultural factors refer to the relationships of individuals with the surrounding social and cultural environment, whilst environmental factors refer to the effects of the physical environment on behaviour (e.g. the accessibility to services). This means that behaviour is influenced by multilevel effects that can act simultaneously. As a result, this framework has been a key foundation for several studies analysing older people's mobility (e.g. Hough et al., 2008; Winters et al., 2015). Correspondingly, using previous literature, Mercado and Newbold (2009) summarised the key determinants of mode choice in later life as being age, gender, mobility tools, health, social issues and other factors such as financial status, education level and urban structure.

When analysing the transport mode determinants for older people's leisure trips in the Netherlands, Schwanen et al. (2001) showed that their choice was linked to personal factors (e.g. education level, age, household composition), car ownership and characteristics of the residential environment. For example, they showed that when older people owned a vehicle they used it irrespective of where they lived. The environment only affected modal choice when older people did not own a car, and public transport was not an actual alternative to the car. For shopping trips in London, Schmöcker et al. (2008) also showed a strong preference towards car use when a car was available in the household, and public transport modes were not preferred. Age and disability also affected public transport use. When analysing mode choice of older people in Washington State, Kim and Ulfarsson (2004) found that personal, household and neighbourhood characteristics were key determinants. For example, higher income levels resulted in older people driving and carpooling more whilst proximity to public transport increased its usage. The latter was a key determinant in several other studies, showing the importance of public transport accessibility for its usage (e.g. Beimborn et al., 2003; Schmöcker et al., 2008; Su et al., 2009).

Different studies showed that gender is a key determinant for mode 
choice in later life since older males are likely to drive more than females (e.g. Siren and Hakamies-Blomqvist, 2004; Su and Bell, 2012). When older females drive they also tend to give up on driving earlier than males (Siren and Hakamies-Blomqvist, 2004), and they tend to travel more as passengers and with public transport (e.g. Böcker et al., 2016; Li et al., 2012). Older women tend to rely more on their husbands to drive them so the loss of spouse usually limits their mobility (Hough et al., 2008). Such loss is a key determinant for social isolation if alternatives, namely access to a car as passengers and public transport systems are not available (Hensher, 2007). Other studies also highlighted the positive correlation between participation in social activities and mobility in later life (e.g. Schwanen and Páez, 2010). The geographic context and neighbourhood design can also be a key influential factor. For example, high density mixed land uses tend to encourage walking and public transport use whilst diminishing driving for shorter distances (e.g. Chudyk et al., 2015; Srichuae et al., 2016). Older people living in rural and suburban areas also tend to drive more since they usually suffer from public transport deficiencies and a higher need to travel longer distances to access basic services (e.g. Hough et al., 2008; Lee et al., 2014).

Given this, one may summarise the key factors that most studies used as determinants for mode choice as age, gender, health, income, driving licence and car ownership, social factors, neighbourhood design, geographic context and access to transport services. Using the multilevel conceptual ecological model as framework, this paper will assess the impacts of these determinants on older people's mode choice in Malta.

\section{The case study of Malta}

Research on travel behaviour in later life covers different geographic scales and contexts. It ranges from international studies (e.g. Rosenbloom, 2001) to local ones (e.g. Páez et al., 2007). However, not all developed countries have been studied to the same extent. Travel behaviour of older people living in small island states like Malta has received limited attention. In Malta, the only research dealing with travel patterns of people is the National Household Travel Survey (carried out in 1989, 1998 and 2010) (TM, 2010). Yet, no specific focus is given to the older population in such survey. The recent trends in the transport sector in Malta as well as its demographic, cultural and geographic contexts have considerable impacts on how people travel. This makes such paper a well-needed resource for transport policy-makers.

Malta is an island state $\left(316 \mathrm{~km}^{2}\right)$ in the central Mediterranean with a population of 429,344 in 2014 (NSO, 2016). Malta is an archipelago with two sister islands, Gozo and Comino. Although the island of Gozo has several similarities to Malta it also differs considerably since it has a distinctive set of socio-cultural characteristics (NSO, 2014a). In a land area of $67 \mathrm{~km}^{2}$, Gozo has a resident population of around 31,000 people. Comino is an uninhabited island. Malta is divided into 68 local councils which are grouped into six districts (Fig. 1).

Malta has been a member of the European Union since 2004, and has the highest population density amongst all member states (1325 persons $/ \mathrm{km}^{2}$ compared to the EU average of 117 persons $/ \mathrm{km}^{2}$ ). Despite the very small geographic size, in 2014, Malta was also the second country in Europe (after Liechtenstein) with the highest rate of motorisation (625 cars/1000 inhabitants) (Eurostat, 2016). Public transport in Malta is served primarily by buses. Prior to 2011 the bus service operated as a private-based monopoly. The bus service reform of 2011 saw the introduction of competitive tendering with the first ever international operator being awarded the contract to operate all services. The services however were nationalised in 2014 after the cancellation (by Government) of the contract with the operator. Subsequently Government published again the tender for services which was awarded in 2015 to the current incumbent (Bajada and Titheridge, 2016).

Together with the impacts of high motorization, Malta is also being faced with a rapidly ageing population. Between the last two census in 2005 and 2011, the older population $(60+)$ increased by $28 \%$, representing $23.7 \%$ of the population in 2011 (NSO, 2014b). Such figures are also projected to increase in the future (National Commission for Active Ageing, 2013). After recent legislative changes, the retirement age in Malta was changed to 65 years. Prior to this, the pension age was set at 61 years old in the case of males and at 60 years old for females. Yet such change was introduced in a gradual manner and currently depends on the year when individuals were born and the number of tax contributions paid. Despite this, in Malta, people are considered as "old" over the age of 60 years (Government of Malta, 2012). This is the year when a special Identification Card called Kartanzjan is issued to the public by the Government indicating that they are "older people". This entitles them to a variety of concessionary and discounted services. Actually, for public transport, a fare concession is available to Kartanzjan Holders (Maltese $60+$ ) and to holders of Special Identification Cards issued by the National Commission for Persons with Disabilities. Such card entitles them to discounted fares (Euro 0.25 for one journey up to $2 \mathrm{~h}$ when compared to Euro 0.75 for the rest of the population). Moreover, people are entitled to participate in Active Ageing Communities in Malta as from the age of 60 . Therefore, given the current different retirement ages and the national fixed age of 60 years that entitles individuals for older age benefits, this was the threshold age used in this paper.

Between 2009 and 2014, the number of older drivers $(60+)$ increased by $32.8 \%$. The increase was more significant for older females $(+56.6 \%)$ than for males $(+26.1 \%)$. A driving licence in Malta is valid for ten years. Yet, for drivers over the age of 70 years it is valid for five years. Upon the renewal process, a driving licence medical certification form has to be filled by a medical doctor indicating whether the driver is fit to continue driving or not. Maltese older people are also higher public transport users when compared to younger demographic cohorts (ICCSD, 2014). Despite this, older people's mobility does not feature in the islands' transport policy. This paper tackles the choice between car driving and public transport use in later life. Unfortunately no data about walking and cycling in later life is available for the islands' population. Despite some improvements in the recent years, Malta is not yet equipped with the appropriate cycling infrastructures. In a Eurobarometer mobility survey in 2013, Malta had one of the lowest levels of cycling in the European Union. In 2014, 93\% of the total population claimed that they never cycle (TM, 2016). Such situation is further accentuated for older people who may suffer from different health limitations. For these reasons, such modes of transport were excluded from this study.

\section{Data and methods}

\subsection{The sample}

The study was carried out in 2016. The last census data showed that the total number of older people in Malta, excluding those residing in institutions, was 93,758 (NSO, 2014b). This was the total population figure from which a sample of 500 people was utilised. Using a maximum margin of error of 5\% and a 95\% confidence level, the minimum required sample was 383. Yet, for a better representation of the older population in Malta, 500 people were utilised. Following this, stratified sampling was used and age groups were divided into three cohorts: 60-69, 70-79 and $80+$. Random sampling was carried out within each cohort to determine the sampled population. The Maltese Electoral Register (October 2015) was the basic source of information used to extract the sample. All the individuals with an Identification Number ending with 56 or less were listed. This type of selection process was chosen since in Malta the last two digits of the identification number represent the year when the person was born. Hence, all the individuals that were 60 years (born in 1956) or over were extracted. The sample of the study divided by age, gender and district is shown in Table 1. 


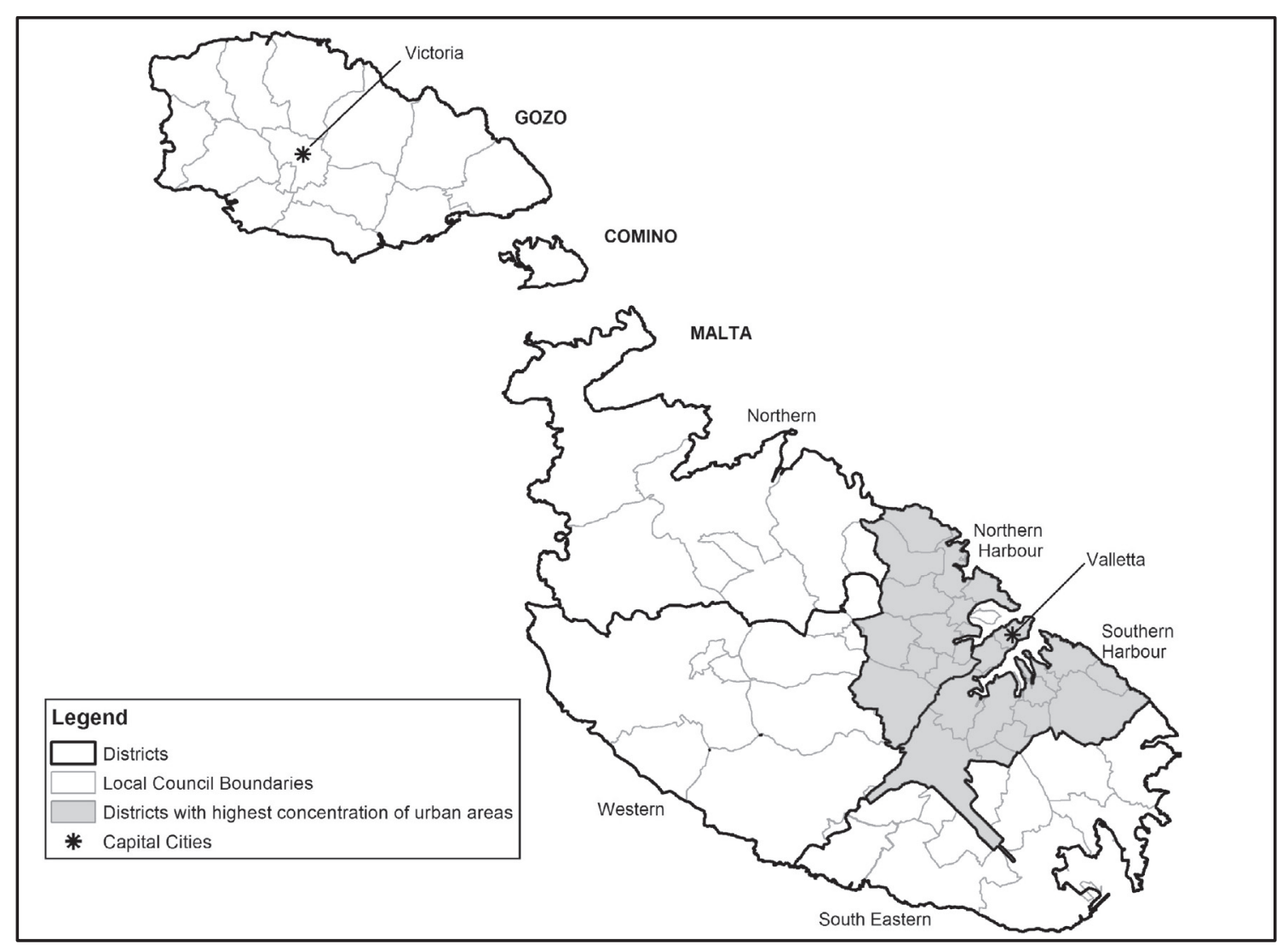

Fig. 1. The six districts in Malta (Drawn by authors).

\subsection{Research design}

A telephone-based survey was used and all telephone numbers were determined through a telephone directory online search. In order to achieve the targeted sample of 500 older people, 713 were called. There were 213 who refused to participate in the survey, resulting in a response rate of $70 \%$. Following the multilevel conceptual ecological model (Section 2.1), this paper discusses the personal, social and environmental predictors of older people's travel behaviour. Table 2 lists all the variables and their respective categories. The "physical health" and "mental health" variables were self-reported. Self-reported health data can be significantly associated with the actual diagnoses (Ernsth Bravell et al., 2011) and can serve as a simple and inexpensive tool for identifying those at high risk of future disability (Mänty et al., 2007).
With regard to the dependent variables concerning mode choice, a binary question was used to determine whether older people were drivers or not (yes/no), whilst a categorical ordinal question was used to determine their public transport usage (daily $=1$, weekly $=2$, monthly $=3$, infrequently $=4$, never $=5$ ). This paper was part of a wider study, and the questions' format variation determined the choice of the respective regression models to be used.

\subsection{Analytical techniques}

In order to derive descriptive statistics, the Pearson Chi Square, Kruskal Wallis and Mann-Whitney correlation tests were used. Subject to the question's structure, the Pearson Chi Square Test was utilised to analyse the association between two categorical variables, whilst the

Table 1

Sample of the study by age, gender and district.

\begin{tabular}{|c|c|c|c|c|c|c|c|c|}
\hline & & \multicolumn{6}{|l|}{ District } & \multirow[t]{2}{*}{ Total (N) } \\
\hline & & Northern Harbour & Southern Harbour & South Eastern & West & Northern & Gozo & \\
\hline \multirow[t]{3}{*}{$60-69$} & Males & 24 & 17 & 22 & 14 & 6 & 19 & 102 \\
\hline & Females & 26 & 46 & 23 & 21 & 22 & 37 & 175 \\
\hline & Total & 50 & 63 & 45 & 35 & 28 & 56 & 277 \\
\hline \multirow[t]{3}{*}{ 70-79 } & Males & 9 & 12 & 5 & 3 & 3 & 5 & 37 \\
\hline & Females & 20 & 23 & 12 & 15 & 11 & 27 & 108 \\
\hline & Total & 29 & 35 & 17 & 18 & 14 & 32 & 145 \\
\hline \multirow[t]{3}{*}{$80+$} & Males & 6 & 5 & 2 & 5 & 0 & 4 & 22 \\
\hline & Females & 8 & 14 & 7 & 5 & 7 & 15 & 56 \\
\hline & Total & 14 & 19 & 9 & 10 & 7 & 19 & 78 \\
\hline \multirow[t]{3}{*}{ Total } & Males & 39 & 34 & 29 & 22 & 9 & 28 & 161 \\
\hline & Females & 54 & 83 & 42 & 41 & 40 & 79 & 339 \\
\hline & Total & 93 & 117 & 71 & 63 & 49 & 107 & 500 \\
\hline
\end{tabular}

The numbers in bold represent the total number of older people (males and females) per district and then the overall total (N) per district. 
Table 2

The independent (personal, social and environmental factors) and dependent variables (mode choice) used in the study.

\begin{tabular}{|c|c|c|}
\hline & Variable & Categories \\
\hline \multirow[t]{16}{*}{ Independent variables } & District of residence ${ }^{c}$ & Southern Harbour (SH)/Northern Harbour (NH)/North (N)/South Eastern (SE)/West (W)/Gozo (G) \\
\hline & Gender ${ }^{\mathrm{a}}$ & Males/females \\
\hline & $\operatorname{Age}^{\mathrm{a}}$ & Continuous $(60+)$ \\
\hline & Marital Status ${ }^{b}$ & Single (single, separated, widow)/married \\
\hline & Education $^{\mathrm{a}}$ & No schooling/primary/secondary/tertiary \\
\hline & Household type ${ }^{\mathrm{b}}$ & Single-household/multi-member \\
\hline & Occupation $^{\mathrm{a}}$ & Work/housewife/inactive or unemployed/retired \\
\hline & Person assisting ${ }^{\mathrm{b}}$ & Yes/no \\
\hline & Participation in social activities ${ }^{\mathrm{b}}$ & Yes/no \\
\hline & Physical Health ${ }^{\mathrm{a}}$ & Bad (ratings 1 and 2)/Neutral (rating 3)/good (ratings 4 and 5) \\
\hline & Mental Health ${ }^{\mathrm{a}}$ & Bad (ratings 1 and 2)/Neutral (rating 3)/good (ratings 4 and 5) \\
\hline & Medicine in-take ${ }^{\mathrm{a}}$ & Prescribed/Over the counter/no medicine \\
\hline & Fall in previous year ${ }^{a}$ & Yes/no \\
\hline & Assistive device ${ }^{\mathrm{a}}$ & Yes (hearing aid, wheelchair, stick, rollator or any other mobility-aiding device/no \\
\hline & Cars in household ${ }^{\mathrm{a}, \mathrm{d}}$ & No cars $/ 1-2$ cars $/ 3-4$ cars $/ 5-6$ cars/driver \\
\hline & Distance to bus stop ${ }^{c}$ & Continuous (in minutes) \\
\hline \multirow[t]{2}{*}{ Dependent variables } & Driver & Yes/no \\
\hline & Public transport use & Daily, weekly, monthly infrequently, never \\
\hline
\end{tabular}

a Individual factors.

bocial factors.

c Environmental factors.

d The question concerning the number of cars in household was only intended for the non-drivers. Therefore, it was not used as a predictor of whether older people were drivers or not.

Mann-Whitney and Kruskal Wallis Tests were used to look for statistical differences between two or more independent samples respectively (Field, 2013). Binary regression was used to identify the factors that predicted whether older people were drivers or not, whilst multinomial regression was used to identify the predictors for public transport use. Ordinal regression was not used in the latter model so as to be able to estimate coefficients that capture the differences between all possible pairs of groups. Moreover, the assumption of proportional odds was violated, and thus the model fit was inappropriate (Norusis, 2011). For all statistical tests a significance level $\alpha$ of $5 \%$ was used.

\section{Results}

\subsection{Descriptive statistics: mode choice}

The rate of non-drivers was overall higher $(62.6 \%)$ than that of drivers (37.4\%). However, the main reason for this was the gender imbalance in the sample (Table 1). From all the drivers, $70.1 \%$ were males and only $29.9 \%$ were females. A Chi-Square test showed that the association between gender and being a driver was actually statistically significant $(p$-value $=0.000)$. Although for both genders, the number of drivers decreased with age, the percentage of male drivers was consistently higher than that of females for all age groups (Fig. 2). As age increased, there were higher discrepancies for females than for males with regard to whether they were drivers or not. This was expected since female older drivers are a relatively recent trend in the islands. Using a Chi-Square test, for both genders the association between age and being a driver was statistically significant ( $p$ -

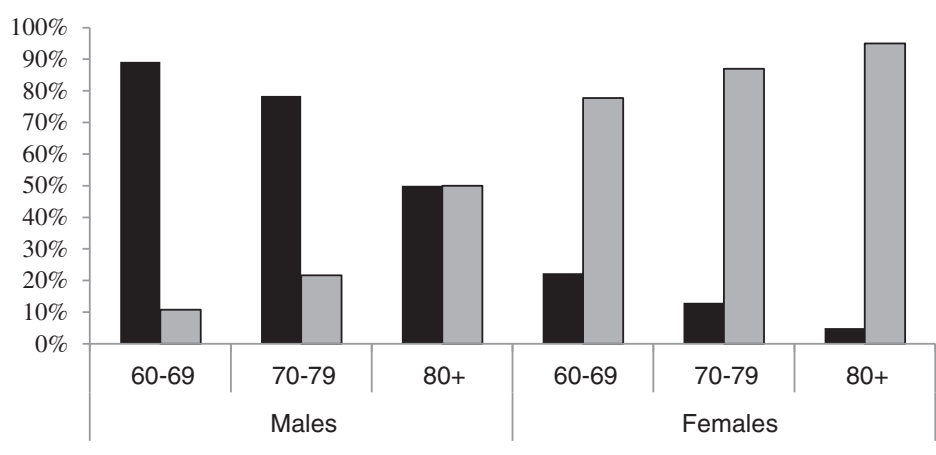

value $=0.000$ for males and $p$-value $=0.015$ for females). Of the nondrivers who responded to the survey, $14.4 \%$ used to drive. The higher percentage of older male drivers reflects the fact that $67 \%$ of those who had to give up driving were females. The main reasons for driving cessation were health limitations (36\%), the perceived traffic and parking difficulties (31\%), fear (11\%) and reliance on relatives (7\%).

A low public transport usage was very evident amongst the older Maltese population. This is because $37.2 \%$ used public transport infrequently, followed by $34.8 \%$ who never used it. This contrasted by $3.2 \%$ and $18.6 \%$ who used it on a daily and weekly basis respectively. Differences between genders was also noticed (Fig. 3). For frequent bus use the percentage of females exceeded that of males. Correspondingly, the percentage of males who never used public transport exceeded that of females. However when a Mann-Whitney Test was conducted to analyse the correlation between gender and public transport use, this resulted to be insignificant ( $p$-value $=0.127$ ). Results also showed that only the younger-old (particularly females) used public transport daily. Additionally, whilst the percentage of weekly-bus users decreased by age for females, for males the pattern was quite unstable. Even with regard to infrequent use, whilst for females a consistent decline with age was noticed, for males the pattern was more fluctuating (Fig. 3).

This means that whilst for females, public transport use decreased with age, for males the pattern was not that linear. This was supported by Kruskal Wallis correlation tests and their respective post-hoc analysis. For females there were two significant relationships: between the 60-69 group and the $80+$ groups; and between the 70-79 and $80+$ groups. In all cases, the older the age the lower was the public transport use $(p$-value $=0.000)$. For males, the relationship between age and

Fig. 2. The driving and non-driving older population divided by age and gender. 


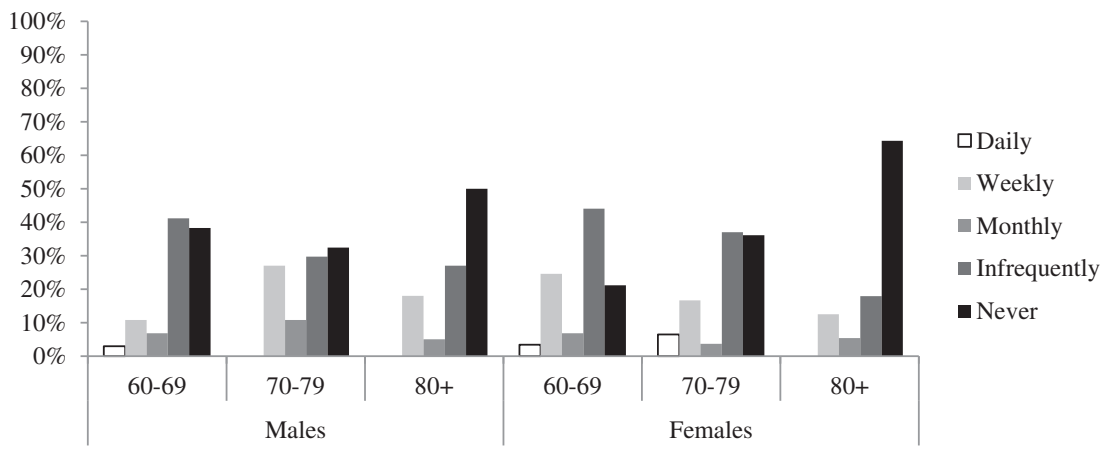

public transport usage was not statistically significant ( $p$ value $=0.369$ ).

Given the high motorization rate in Malta, it was also important to understand whether those who used public transport were captive or choice users. The highest percentage of drivers $(43.3 \%)$ used public transport in an infrequent manner, or else did not use it at all (41.2\%). On the other hand, $23.6 \%$ of the non-drivers used public transport weekly compared to only $10.2 \%$ who were drivers. This shows that public transport usage was the highest amongst the non-drivers, meaning that these can potentially be captive-users. This was supported by a Mann-Whitney statistical test which showed that for both genders, the correlation between driving and public transport use was statistically significant ( $p$-value $=0.001$ for females and 0.007 for males).

\subsection{Determinants of mode choice}

Regression models were used to model the predictors for mode choices. The independent variables, used as predictors in the two regression models, are summarised in Table 2.

\subsubsection{Model 1: driver or not}

From all the variables inputted in the model (Table 2), the only ones that proved to be significant predictors for whether older people drove or not are shown in chronological order in Table 3. Their respective model results are also listed. The non-significant variables will also be discussed in Section 6.

As expected, gender was the most important predictor in this model, with males being more likely to be drivers than females. For females the odds to be a driver were $95.8 \%$ lower than males. Such findings correlated with national statistics that showed that in 2014 the number of $60+$ male drivers $(38,575)$ exceeded that of females $(97,722)$ by 47,110 (NSO, 2015). Yet, this pattern is expected to change due to the rapid increase in the number of old female drivers.

Older people who still worked had a higher tendency to be drivers than older people who registered as housewives, retired or inactive. The
Fig. 3. Older people's public transport usage by age and gender.

highest discrepancy was between those who worked and those who were inactive. For workers, the odds of being a driver when compared to not driving were 12.7 more likely than those who were inactive (Table 3). Workers may travel more by car since they can be more restricted with time when compared to the other groups. The majority (97.4\%) of older people who worked were between 60 and 69 years old. Being "younger-old" was a key reason for this higher driving rate. Age was the third most important predictor in this model. For every one year increase in age, the odds of being a driver reduced by $7.4 \%$. Finally, corresponding with the age predictor, the model showed that older people with an assistive device (hearing aid, wheelchair, stick, rollator or any other mobility-aiding device) were almost $50 \%$ less likely to be drivers than those that did not require such assistance. Such finding is quite reasonable since assistive devices are usually associated with physical limitations that can constrain driving.

\subsubsection{Model 2: public transport use}

The significant predictors for older people's public transport use were the number of cars available in household ( $p$-value $=0.000$ ), age $(p$-value $=0.000), \quad$ district $\quad(p$-value $=0.001), \quad$ occupation $\quad(p$ value $=0.002)$, participation in social activities $(p$-value $=0.002)$ and personal assistance ( $p$-value $=0.007)$. These variables and their respective model results are shown in Table 4. The reference category used in the model was of "never" using public transport. This was done in order to specifically highlight the reasons that cause older people to not use public transport at all. The non-significant variables will be further discussed in Section 6.

This model showed that the number of cars available in the household was the primary predictor for public transport usage in later life. As discussed previously, the model also showed that drivers had a significantly lower use of public transport than the non-drivers. For example, the odds of non-drivers with 1-2 cars available to use public transport on a weekly basis rather than never using it were four times more likely than drivers. The most common correlation was between the drivers and the non-drivers that did not have any cars available.

Table 3

Review of significant variables (in chronological order) in regression analyses predicting whether older people were drivers or not.

\begin{tabular}{|c|c|c|c|c|c|c|c|}
\hline \multirow[t]{2}{*}{ Order } & \multirow[t]{2}{*}{ Variable } & \multicolumn{2}{|l|}{ Categories } & \multicolumn{4}{|c|}{ Model results } \\
\hline & & & & B & S.E. & Exp (B) & $p$-Value \\
\hline & Constant & & & 7.172 & 1.401 & & \\
\hline 1 & Gender & Females & Males & -3.178 & 0.325 & 0.042 & 0.003 \\
\hline \multirow[t]{3}{*}{2} & Occupation & Work & Retired & 1.419 & 0.48 & 4.132 & 0.003 \\
\hline & & Work & Housewife & 2.051 & 0.49 & 7.778 & 0.000 \\
\hline & & Work & Inactive & 2.544 & 0.79 & 12.728 & 0.001 \\
\hline 3 & Age & & & -0.077 & 0.019 & 0.926 & 0.000 \\
\hline 4 & Assistive device & Yes & No & -0.746 & 0.315 & 0.474 & 0.018 \\
\hline
\end{tabular}

Reference category: driver.

Fit of model $=0.000(p$-value $<0.05)$.

Cox and Snell's $\mathrm{R}^{2}=0.403$.

Nagelkeke's $\mathrm{R}^{2}=0.549$. 
Table 4

Review of significant variables in regression analyses predicting older people's public transport use.

\begin{tabular}{|c|c|c|c|c|c|c|c|}
\hline \multirow[t]{2}{*}{ Public transport use } & \multirow[t]{2}{*}{ Predictor } & \multicolumn{2}{|l|}{ Categories } & \multicolumn{4}{|c|}{ Model results } \\
\hline & & & & B & S.E & $\operatorname{Exp}(B)$ & $p$-Value \\
\hline \multirow[t]{7}{*}{ Daily } & Constant & & & -3.839 & 3.419 & & \\
\hline & Number of cars available & 0 & Driver & 3.117 & 1.171 & 22.571 & 0.008 \\
\hline & & 0 & $1-2$ & 2.845 & 0.876 & 17.225 & 0.001 \\
\hline & District & $\mathrm{NH}$ & G & 2.774 & 1.124 & 16.028 & 0.014 \\
\hline & & $\mathrm{W}$ & G & 2.701 & 1.28 & 14.89 & 0.035 \\
\hline & & $\mathrm{N}$ & $\mathrm{G}$ & 3.321 & 1.232 & 27.678 & 0.007 \\
\hline & Occupation & Housewife & Work & -2.084 & 1.059 & 0.124 & 0.049 \\
\hline \multirow[t]{15}{*}{ Weekly } & Constant & & & -0.553 & 1.537 & & \\
\hline & Number of cars available & 0 & Driver & 3.115 & 0.707 & 22.534 & 0.000 \\
\hline & & $1-2$ & Driver & 1.378 & 0.38 & 3.967 & 0.000 \\
\hline & & $3-4$ & Driver & 1.311 & 0.539 & 3.708 & 0.015 \\
\hline & & 0 & $1-2$ & 1.737 & 0.677 & 17.225 & 0.001 \\
\hline & & 0 & $3-4$ & 1.804 & 0.771 & 6.077 & 0.019 \\
\hline & Age & & & -0.06 & 0.021 & 0.942 & 0.004 \\
\hline & District & SH & G & 2.381 & 0.537 & 10.814 & 0.000 \\
\hline & & $\mathrm{NH}$ & G & 2.471 & 0.570 & 11.837 & 0.000 \\
\hline & & SE & G & 2.431 & 0.576 & 11.371 & 0.000 \\
\hline & & $\mathrm{W}$ & G & 1.832 & 0.622 & 6.244 & 0.003 \\
\hline & & $\mathrm{N}$ & G & 1.650 & 0.693 & 5.206 & 0.017 \\
\hline & Occupation & Retired & Work & 1.572 & 0.719 & 4.815 & 0.029 \\
\hline & Participation in social activities & Yes & No & 1.02 & 0.335 & 2.773 & 0.002 \\
\hline & Personal assistance & Yes & No & -1.357 & 0.431 & 0.257 & 0.002 \\
\hline \multirow[t]{6}{*}{ Monthly } & Constant & & & -16.634 & 2.156 & & \\
\hline & Number of cars available & 0 & Driver & 2.097 & 0.917 & 8.144 & 0.022 \\
\hline & Age & & & -0.073 & 0.03 & 0.929 & 0.015 \\
\hline & District & $\mathrm{NH}$ & G & 1.709 & 0.714 & 5.521 & 0.017 \\
\hline & & $\mathrm{W}$ & G & 1.469 & 0.745 & 4.344 & 0.049 \\
\hline & Participation in social activities & Yes & No & 1.094 & 0.454 & 2.985 & 0.016 \\
\hline \multirow[t]{9}{*}{ Infrequently } & Constant & & & 3.409 & 1.141 & & \\
\hline & Age & & & -0.074 & 0.017 & 0.928 & 0.000 \\
\hline & District & SH & G & 0.962 & 0.343 & 2.618 & 0.005 \\
\hline & & NH & G & 1.247 & 0.367 & 3.481 & 0.001 \\
\hline & Occupation & Retired & Work & 1.036 & 0.429 & 2.817 & 0.016 \\
\hline & & Housewife & Work & 1.217 & 0.482 & 3.378 & 0.012 \\
\hline & & Inactive & Work & 1.608 & 0.737 & 4.991 & 0.029 \\
\hline & Participation in social activities & Yes & No & 0.954 & 0.278 & 2.595 & 0.001 \\
\hline & Personal assistance & Yes & No & -0.654 & 0.29 & 0.52 & 0.024 \\
\hline
\end{tabular}

Reference Category: never using use public transport.

Fit of the model $=0.000$ ( $p$-value $<0.05)$.

Cox and Snell's $\mathrm{R}^{2}=0.331$.

Nagelkerke $\mathrm{R}^{2}=0.356$

Yet, being a driver was also statistically different from the non-drivers that actually had cars available. For example, the odds for non-drivers with 3-4 cars available were three times more likely to use public transport weekly rather than never when compared to drivers. There were significant correlations even between the non-drivers themselves, depending on the number of cars available. For example, the odds that non-drivers with no cars available use public transport on a weekly basis rather than never were six times as much as the non-drivers with 3-4 cars available. This shows that when the non-drivers had cars available to them, the probability to not use public transport was high.

Similar to Model 1, age also proved to be a significant predictor for public transport usage. For every one year increase the odds that older people used public transport on a weekly basis rather than never using it decreased by $5.8 \%$. A similar pattern was recorded for monthly and infrequent use of public transport. This shows that as age increased the probabilities to travel both as drivers and as public transport users decreased, which is an indication of a general decline in mobility (refer also to Section 1). Surprisingly, unlike for Model 1, the district where older people resided was the third most important predictor for public transport use. The district which significantly differed from the others was Gozo. Public transport was used significantly less than in the other districts in Malta (Table 4). For example, the odds that older people residing in the Western district used public transport on a monthly manner compared to never using it were four times more likely than those living in Gozo.

The occupation status of older people was the fourth factor that significantly predicted public transport use. When compared to older people who worked, housewives used public transport significantly less on a daily basis rather than never using it $(B=-2.084)$. Yet, the model also showed that workers had a higher probability than those who were retired, housewives or inactive to never use public transport rather than using it on a weekly or infrequent manner (Table 4). Thus, the model is not showing that older people who worked were high public transport users. It is showing that when comparing the frequency of use, workers who used public transport had a higher probability than the other groups to use it more on a daily basis, probably for commuting. Another factor was the younger age of those who worked. This explains their higher representation for daily bus use since the younger the age, the higher the public transport use (Section 5.1). The argument that older people who worked tended to be non-bus users was supported in this model. This reinforced what was discussed in Model 1 where workers had a higher tendency to be drivers.

Unlike Model 1, this model showed that participation in social activities was a significant determinant for public transport use. Those who participated in some sort of social activities used public transport more frequently than those who did not. For example, the odds for those who participated in social activities to use public transport weekly rather than never were almost three times more than for those 
who did not participate in any social activity. One possible explanation for this could be that when participating in social activities older people tend to be healthier (Leyden, 2003), and thus feel more confident to use public transport. Ultimately, the model showed that older people with personal assistance used public transport less than those who did not require any assistance $(\mathrm{B}=-1.357$ when comparing weekly with never and $\mathrm{B}=-0.654$ when comparing infrequently with never). Such finding was mostly related to the age of respondents because personal assistance increased as they got older. Therefore, since this same model showed that with an increase in age public transport use declined, it could also be concluded that since personal assistance increased with age, both factors led to a lower public transport usage.

\section{Discussion and summary of findings}

This paper showed that whilst some findings concerning older people's mode choice in Malta were supported by previous studies, others did not. The literature review (Section 2.1) showed how gender differences with regard to driving were very significant with a higher percentage of male drivers. Yet, the percentage of drivers declined with age. This links with the driving cessation phenomenon since the older an individual gets, the higher the probability to cease driving. As a result of this, one would expect that older people would rely more on public transport as an alternative. However, in Malta this did not prove to be the case since public transport usage was overall low and further declined with an increase in age. This shows that public transport in Malta is not yet catering enough for the older-old since they may still prefer to travel by car (particularly as passengers). Although similar to other studies results showed that older females used public transport more than males, the correlation between gender and public transport use proved to be insignificant. This shows that although females tend to be more "transport disadvantaged" (Lucas et al., 2001), unlike for driving, gender did not affect public transport use. The correlation between age and public transport use for males was also insignificant. Hence, in Malta, public transport use particularly for older males, requires further research to better understand its patterns and determinants.

This was supported by the two regression models used to analyse the determinants of mode choice since gender was not a significant predictor for public transport use. This shows that although both models were related to mode choice they had different predictors. The only two variables that predicted both modes were age and older people's occupation status. Age was a negatively correlated variable for both modes, and workers had a higher probability to drive and a lower probability to use public transport. This perfectly supported other research such as that of Hildebrand (2003). When clustering older people based on their lifestyles, the latter showed that workers made $93.2 \%$ and $1.3 \%$ of their trips by car and public transport respectively.

Similar to other studies (e.g. Schmöcker et al., 2008) this paper showed that when a car was available in the household, public transport use tended to be lower. This research further reinforced the argument that the bus in Malta is mostly used by captive users, and that it is not yet an adequate alternative to the car even for non-drivers. Despite the small size of the islands, there were contrasting results in terms of public transport use between the five districts in Malta and Gozo, which is an island-district on its own. The latter proved to have a lower public transport usage when compared to the districts in Malta. This supported the fact that in many ways, including land use patterns and transport systems, Gozo is different from Malta (Section 3). Further research is needed on such spatial differences, and both transport planners and policy-makers need to consider them when working towards improving public transport services.

This study showed a positive correlation between participation in social activities in later life and public transport use. Although this may be an indication of better health, this was not statistically proven in this paper. Further research is required in Malta to better understand the profile of older people who participate in social activities and their respective travel patterns. Correspondingly, the two regression models showed that when older people had an assistive device (Model 1) and when they had personal assistance (Model 2), they had lower probabilities of driving and using public transport.

Although this paper discussed the significant factors that predicted mode choice of older people, it is equally important to highlight those variables which did not have any significant effect (Table 2). In Model 1 these were district, marital status, education, household type, personal assistance, participation in social activities, perception of physical and mental health, medicine intake, fall in previous year and distance to bus stop. This means that, for example, there were no spatial factors affecting older people's decision to drive or not. This is very realistic given the high car ownership throughout the islands (NSO, 2015). The lack of significant factors predicting whether older people were drivers or not (e.g. family structure, education levels, health perception etc.) is also an indication that driving in Malta can be more related to habit. Mode choice can be a strong habitual practice and it was actually included in several models that analysed mode choice (e.g. Gärling and Axhausen, 2003; Verplanken et al., 1998).

With regard to public transport use, the non-significant determinants were gender, marital status, household type, education level, perception of physical and mental health, medicine intake, fall in previous year, presence of an assistive device and distance to bus stop. From these, the two most interesting variables were older people's perception on their health status and the distance to bus stop. Although public transport use decreased with age, and those who had a person assisting them used public transport less, older people's perceptions of their health did not affect their decision to use public transport. This complemented Chan et al. (1998) who showed that the ability to use public transport did not influence the older persons' perception of health in Singapore. Model 1 had a similar finding because although older people with an assistive device drove less, health perceptions did not affect their driving decision. This showed that physiological changes were not a major predictor for older people's mode choice in Malta. Contrasting with research from other contexts (e.g. Beimborn et al., 2003; Schmöcker et al., 2008; Su et al., 2009), proximity to bus stops did not affect public transport use, despite $81.8 \%$ of the older people living within less than five minutes from a bus stop.

Since no similar studies have ever been carried out in Malta, the exploratory findings of this paper provide much needed information for policy on older people's mode choice. Nonetheless, it is acknowledged that there are also some limitations. This paper focused on the older people's travel behaviour without assessing the characteristics of the transport system in the islands. Important factors as the cost of transport, its efficiency and its accessibility were not included. Older people in Malta tend to encounter several barriers when using public transport due to different factors such as the lack of comfort on bus stops (Mifsud and Attard, 2013). Hence, these could be key determinants for their mode choice. Another limitation of this paper is that mode choice was discussed in a generic way rather than for specific travel purposes. So, it is suggested that further research in Malta will analyse the travel purposes and patterns of older people using such modes of transport, and the resultant implications on both themselves and society. For example, high car use can negatively affect health status due to the lack of physical movement. Additionally, following the multilevel conceptual ecological model, this study focused only on the personal, social and environmental determinants of mode choice excluding any psychological factors. Two such important factors are actually older people's attitudes towards the different modes of transport (Haustein, 2012) and their habitual practices. Working towards breaking the car-use habit can be a difficult task (Verplanken et al., 2008). However it is indispensable, particularly in motorised ageing societies like Malta. Thus, following this exploratory phase, further research is needed to overcome such limitations and understand in more depth older people's mobility in the islands. A qualitative approach in this regard would also 


\section{be beneficial.}

\section{Conclusion}

This study showed that Maltese older people, particularly males, are high car users and most of them use public transport in an infrequent manner. It also showed that such modes of transport are affected by different personal, social and environmental determinants. Given the demographic changes and high motorisation rate in Malta, such results suggest that transport strategies should move beyond the private car. Policy-makers should not just work on breaking the car-driving habit amongst younger people, but also in later stages of life. This should be complemented by incentives and educational campaigns that encourage alternative modes of transport. This paper provides much needed evidence to help transport policy-makers understand the motivations for how older people travel, and thus determine the best policies to meet the mobility needs of ageing societies like Malta.

\section{References}

Anstey, K.J., Wood, J., Lord, S., Walker, J.G., 2005. Cognitive, sensory and physical factors enabling driving safety in older adults. Clin. Psychol. Rev. 25 (1), 45-65. http://dx.doi.org/10.1016/j.cpr.2004.07.008.

Bajada, T., Titheridge, H., 2016. To contract or to operate publicly? Observations from the bus service reform transition process in Malta. Res. Transp. Econ. 59, 281-291. http://dx.doi.org/10.1016/j.retrec.2016.07.007.

Banister, D., Bowling, A., 2004. Quality of life for the elderly: the transport dimension. Transp. Policy 11, 105-115. http://dx.doi.org/10.1016/S0967-070X(03)00052-0.

Beimborn, E.A., Greenwald, M.J., Jin, X., 2003. Transit accessibility and connectivity impacts on transit choice and captivity. Transp. Res. Rec. 1835, 1-9. http://dx.doi. org/10.3141/1835-01

Böcker, L., van Amen, P., Helbich, M., 2016. Elderly travel frequencies and transport mode choices in greater Rotterdam, the Netherlands. Transportation 1-22. http://dx. doi.org/10.1007/s11116-016-9680-z.

Chan, K.M., Pang, W.S., Ee, C.H., Ding, Y.Y., Choo, P., 1998. Self-perception of health among elderly community dwellers in Singapore. Ann. Acad. Med. Singap. 27 (4), 461-467(Available from: https://pdfs.semanticscholar.org/73a4/ 2ae01dc94c74d699130ccb1af2b0324ad93d.pdf [Accessed: 10th February 2017]).

Chandraratna, S., Stamatiadis, N., 2003. Problem driving maneuvers of elderly drivers. Transportation research record. J. Transp. Res. Board 1843 (1), 89-95. http://dx.doi. org $/ 10.3141 / 1843-11$

Chudyk, A.M., Winters, M., Moniruzzaman, M., Ashe, M.C., SimsGould, J., McKay, H., 2015. Destinations matter: the association between where older adults live and their travel behaviour. J. Transp. Health 2 (1), 50-57. http://dx.doi.org/10.1016/j.jth. 2014.09.008.

Collia, D.V., Sharp, J., Giesbrecht, L., 2003. The 2001 national household travel survey: a look into the travel patterns of older Americans. J. Saf. Res. 34, 461-470. http://dx. doi.org/10.1016/j.jsr.2003.10.001.

DaCoTA, 2012. Older Drivers. Deliverable 4.8k of the EC FP7 project DaCoTA. (Available from: http://www.dacota-project.eu/Deliverables/Webtexts/Older\%20Drivers.pdf [Accessed 4th February 2017]).

Davey, J.A., 2007. Older people and transport: coping without a car. Ageing Soc. 27 (1), 49-65. http://dx.doi.org/10.1017/S0144686X06005332.

Engels, B., Liu, G.J., 2011. Social exclusion, location and transport disadvantage amongst non-driving seniors in a Melbourne municipality, Australia. J. Transp. Geogr. 19 (4), 984-996. http://dx.doi.org/10.1016/j.jtrangeo.2011.03.007.

Ernsth Bravell, M., Zarit, S.H., Johansson, B., 2011. Self-reported activities of daily living and performance-based functional ability: a study of congruence among the oldest old. Eur. J. Ageing 8, 199-209. http://dx.doi.org/10.1007/s10433-011-0192-6.

Eurostat, 2016. Motorisation Rate: Cars per 1000 Inhabitants (tsdpc340). (Available from: http://ec.europa.eu/eurostat/tgm/table.do?tab = table\&plugin $=1 \&$ language $=$ en $\&$ pcode $=$ tsdpc 3 [Accessed: 3rd February 2017]).

Fiedler, M., 2007. Older People and Public Transport: Challenges and Chances of an Ageing Society. European Metropolitan Transport Authorities. (Available from: https://www.emta.com/IMG/pdf/Final_Report_Older_People_protec.pdf [Accessed: 3rd February 2017]).

Field, A., 2013. Discovering Statistics Using IBM SPSS Statistics, 4th ed. Sage Publications Ltd.

Gärling, T., Axhausen, K.W., 2003. Introduction: habitual travel choice. Transportation 30, 1-11. http://dx.doi.org/10.1023/A:1021230223001.

Gelau, C., Sirek, J., Dahmen-Zimmer, D., 2011. Effects of time pressure on left-turn decisions of elderly drivers in a fixed-base driving simulator. Transp. Res. F 14, 76-86. http://dx.doi.org/10.1016/j.trf.2010.10.002.

Golob, T.F., Hensher, D.A., 2007. The trip chaining activity of Sydney residents: a crosssection assessment by age group with a focus on seniors. J. Transp. Geogr. 15 (4), 298-312. http://dx.doi.org/10.1016/j.jtrangeo.2006.09.005.

Gössling, S., Cohen, S.A., Hares, A., 2016. Inside the black box: EU policy officers' perspectives on transport and climate change mitigation. J. Transp. Geogr. 57, 83-93. http://dx.doi.org/10.1016/j.jtrangeo.2016.10.002.

Government of Malta, 2012. Kartanzjan. (Available from: http://www.activeageing.gov
mt/en/Pages/Kartanzjan/Kartanzjan.aspx [Accessed: 11th March 2015]).

Haustein, S., 2012. Mobility behaviour of the elderly: an attitude-based segmentation approach for a heterogeneous target group. Transportation 39, 1079-1103. http:// dx.doi.org/10.1007/s11116-011-9380-7.

Hensher, D.A., 2007. Some insights into the key influences on trip-chaining activity and public transport use of seniors and the elderly. Int. J. Sustainable Transp. 1 (1), 53-68. http://dx.doi.org/10.1080/15568310601097004.

Hess, D., 2009. Access to public transit and its influence on ridership for older adults in two U.S. cities. J. Transp. Land Use 2 (1), 3-27. http://dx.doi.org/10.5198/jtlu. v2i1.11.

Hildebrand, E.D., 2003. Dimensions in elderly travel behaviour: a simplified activitybased model using lifestyle clusters. Transportation 30 (3), 285-306. http://dx.doi. org/10.1023/A:1023949330747.

Hjorthol, R.J., Levin, L., Siren, L., 2010. Mobility in different generations of older persons. The development of daily travel in different cohorts in Denmark, Norway and Sweden. J. Transp. Geogr. 18, 624-633. http://dx.doi.org/10.1016/j.jtrangeo.2010. 03.011.

Hough, J.A., Cao, X., Handy, S.L., 2008. Exploring travel behavior of elderly women in rural and small urban North Dakota: an ecological modeling approach. Transportation research record. J. Transp. Res. Board 2082, 125-131. http://dx.doi. org/10.3141/2082-15.

Hounsell, N.B., Shrestha, B.P., McDonald, M., Wong, A., 2016. Open data and the needs of older people for public transport information. Transp. Res. Proc. 14, 4334-4343. http://dx.doi.org/10.1016/j.trpro.2016.05.355.

Institute for Climate Change and Sustainable Development (ICCSD), 2014. Public Transport Customer Satisfaction Surveys. University of Malta, Msida.

Kemperman, A.D.A.M., Timmermans, H.J.P., 2014. Green spaces in the direct living en vironment and social contacts of the aging population. Landsc. Urban Plan. 129, 44-54. http://dx.doi.org/10.1016/j.landurbplan.2014.05.003.

Kim, S., 2011. Assessing mobility in an aging society: personal and built environment factors associated with older people's subjective transportation deficiency in the US. Transp. Res. F 14, 422-429. http://dx.doi.org/10.1016/j.trf.2011.04.011.

Kim, S., Ulfarsson, G., 2004. Travel mode choice of the elderly: effects of personal, household, neighborhood, and trip characteristics. Transportation research record. J. Transp. Res. Board 1894, 117-126. http://dx.doi.org/10.3141/1894-13.

Lee, J.S., Zegras, P.C., Ben-Joseph, E., Park, S., 2014. Does urban living influence baby boomers' travel behavior? J. Transp. Geogr. 35, 21-29. http://dx.doi.org/10.1016/j. jtrangeo.2014.01.004.

Leversen, J.S.R., Hopkins, B., Sigmundsson, H., 2013. Ageing and driving: examining the effects of visual processing demands. Transp. Res. F 17, 1-4. http://dx.doi.org/10. 1016/j.trf.2012.11.003.

Leyden, K.M., 2003. Social capital and the built environment: the importance of Walkable neighborhoods. Am. J. Public Health 93 (9), 1546-1551(Available from: https:// www.ncbi.nlm.nih.gov/pmc/articles/PMC1448008/ [Accessed: 11th February 2017]).

Li, H., Raeside, R., Chen, T., McQuaid, R.W., 2012. Population ageing, gender and the transportation system. Res. Transp. Econ. 34, 39-47. http://dx.doi.org/10.1016/j. retrec.2011.12.007.

Lucas, K., Grosvenor, T., Simpson, R., 2001. Transport, the Environment and Social Exclusion. Joseph Rowntree Foundation, York(Available from: http://citeseerx.ist. psu.edu/viewdoc/download?doi $=10 \cdot 1 \cdot 1 \cdot 474.1977 \&$ rep $=$ rep $1 \&$ type $=$ pdf [Accessed: 10th February 2017]).

Lyman, J.L., McGwin, G., Sims, R.V., 2001. Factors related to driving difficulty and habits in older drivers. Accid. Anal. Prev. 33 (3), 413-421. http://dx.doi.org/10.1016/ S0001-4575(00)00055-5.

Mänty, M., Heinonen, A., Leinonen, R., Törmäkangas, T., Sakari-Rantala, R., Hirvensolo, M., Von Bonsdorff, M.B., Rantanen, T., 2007. Construct and predictive validity of a self-reported measure of preclinical mobility limitation. Arch. Phys. Med. Rehabil. 88, 1108-1113. http://dx.doi.org/10.1016/j.apmr.2007.06.016.

Marottoli, R.A., de Leon, C.F.M., Glass, T.A., Williams, C.S., Cooney, L.M., Berkman, L.F., 2000. Consequences of driving cessation: decreased out-of-home activity levels. J. Gerontol. B Psychol. Sci. Soc. Sci. 55, 334-340. http://dx.doi.org/10.1093/geronb/ 55.6.S334.

Mayhew, D.R., Simpson, H.M., Ferguson, S.A., 2006. Collisions involving senior drivers: high-risk conditions and locations. Traffic Inj. Prev. 7 (2), 117-124. http://dx.doi. org $/ 10.1080 / 15389580600636724$.

Mercado, R., Newbold, K.B., 2009. Car Driving and Public Transit Use in Canadian Metropolitan Areas: Focus on Elderly and Role of Health and Social Network Factors. SEDAP Research Paper No. 243. (Available from: http://socserv.mcmaster.ca/sedap/ p/sedap243.pdf [Accessed: 1st February 2017]).

Mercado, R., Páez, A., 2009. Determinants of distance traveled with a focus on the elderly: a multilevel analysis in the Hamilton CMA, Canada. J. Transp. Geogr. 17 (1), 65-76. http://dx.doi.org/10.1016/j.jtrangeo.2008.04.012.

Mifsud, D., Attard, M., 2013. The role of public transport in addressing sustainable mobility for the elderly population in Malta. Xjenza Online J. Malta Chamber Scientists 47-54. http://dx.doi.org/10.7423/XJENZA.2013.2.06.

Musselwhite, C., Haddad, H., 2010. Mobility, accessibility and quality of later life. Quality Ageing Older Adults 11 (1), 25-37. http://dx.doi.org/10.5042/qiaoa.2010.0153.

National Commission for Active Ageing, 2013. National Strategic Policy for Active Ageing Malta 2014-2020. Valletta, Malta.

Norusis, M.J., 2011. IBM SPSS Statistics 19 Advanced Statistical Procedures Companion. Addison-Wesley, Boston.

NSO (National Statistics Office), 2014a. Malta in Figures 2014. National Statistics Office, Valletta.

NSO (National Statistics Office), 2014b. Census of Population and Housing 2011: Final Report. National Statistics Office, Valletta. 
NSO (National Statistics Office), 2015. Transport Statistics 2015. National Statistics Office, Valletta.

NSO (National Statistics Office), 2016. Demographic Review 2014. National Statistics Office, Valletta.

O'Fallon, C., Sullivan, C., 2009. Trends in older people's travel patterns: Analysing changes in older New Zealanders' travel patterns using the Ongoing New Zealand Household Travel Survey. In: NZ Transport Agency Research Report RR 369. New Zealand Transport Agency, Wellington.

Páez, A., Scott, D., Potoglou, D., Kanaroglou, P.S., Newbold, K.B., 2007. Elderly mobility: demographic and spatial analysis of trip making in the Hamilton CMA, Canada. Urban Stud. 44 (1), 123-146. http://dx.doi.org/10.1080/00420980601023885.

Rogé, J., Ndiaye, D., Vienne, F., 2014. Useful visual field training: a way to improve elderly car drivers' ability to detect vulnerable road users. Transp. Res. F 26, 246-257. http://dx.doi.org/10.1016/j.trf.2014.08.005.

Rosenbloom, S., 2001. Sustainability and automobility among the elderly: an international assessment. Transportation 28, 375-408. http://dx.doi.org/10.1023/ A:1011802707259.

Rudinger, G., Donaghy, K., Poppelreuter, S., 2006. Societal trends, mobility behaviour and sustainable transport in Europe and North America. Eur. J. Transp. Infrastruct. Res. 6 (1), 61-76(Available from: http://www.ejtir.tbm.tudelft.nl/ISSUES/2006_01, pdf/2006 01 04.pdf [Accessed: 5th February 2017]).

Rye, T., Scotney, D., 2004. The factors influencing future concessionary bus patronage in Scotland and their implications for elsewhere. Transp. Policy 11 (2), 133-140. http:// dx.doi.org/10.1016/j.tranpol.2003.09.005.

Sallis, J.F., Owen, N., Fisher, E.B., 2008. Ecological models of health behaviour. In: Glanz, K., Rimer, B.K., Viswanath, K. (Eds.), Health Behavior and Health Education: Theory, Research, and Practice, 4th ed. Jossey-Bass, A Wiley Imprint, San Francisco, pp. 465-485.

Schmöcker, J.D., Quddus, M.A., Noland, R.B., Bell, M.G.H., 2008. Mode choice of older and disabled people: a case study of shopping trips in London. J. Transp. Geogr. 16, 257-267. http://dx.doi.org/10.1016/j.jtrangeo.2007.07.002.

Schwanen, T., Páez, A., 2010. The mobility of older people - an introduction. J. Transp. Geogr. 18, 591-595. http://dx.doi.org/10.1016/j.jtrangeo.2010.06.001.

Schwanen, T., Dijst, M., Dieleman, F.M., 2001. Leisure trips of senior citizens: determinants of modal choice. Tijdschr. Econ. Soc. Geogr. 92, 347-360. http://dx.doi.org/ 10.1111/1467-9663.00161.

Shergold, I., Parkhurst, G., 2012. Transport-related social exclusion amongst older people in rural Southwest England and Wales. J. Rural. Stud. 28 (4), 412-421. Special Issue on Growing Old in Rural Places. http://dx.doi.org/10.1016/j.jrurstud.2012.01.010.

Shrestha, B.P., Millonig, A., Hounsell, N.B., McDonald, M., 2016. Review of public transport needs of older people in European context. Population Ageing 1-19. http:// dx.doi.org/10.1007/s12062-016-9168-9.

Siren, A., Hakamies-Blomqvist, L., 2004. Private car as the grand equaliser? Demographic factors and mobility in Finnish men and women aged $65+$. Transp. Res. F 7, 107-118. http://dx.doi.org/10.1016/j.trf.2004.02.003.

Srichuae, S., Nitivattananon, V., Perera, R., 2016. Aging society in Bangkok and the factors affecting mobility of elderly in urban public spaces and transportation facilities. IATSS Res. 40 (1), 26-34. http://dx.doi.org/10.1016/j.iatssr.2015.12.004 0386-1112.

Su, F., Bell, M.G.H., 2012. Travel differences by gender for older people in London. Res. Transp. Econ. 34 (1), 35-38. http://dx.doi.org/10.1016/j.retrec.2011.12.011.

Su, F., Schmöcker, J.D., Bell, M.G.H., 2009. Mode Choide of older people before and after shopping. J. Transp. Land Use 2 (1), 29-46. http://dx.doi.org/10.5198/jtlu.v2i1.69.

Sundling, C., Emardson, R., Pendrill, L.R., Nilsson, M.E., Berglund, B., 2015. Two models of accessibility to railway traveling for vulnerable, elderly persons. Measurement 72 , 96-101. http://dx.doi.org/10.1016/j.measurement.2015.02.053.

TM (Transport Malta), 2010. National Household Travel Survey. Transport Malta Floriana.

TM (Transport Malta), 2016. National Transport Strategy 2050. Transport Malta, Floriana.

United Nations, Department of Economic and Social Affairs, Population Division, 2015. World Population Prospects: The 2015 Revision - Key Findings and Advance Tables (ESA/P/WP.241). (Available from: https://esa.un.org/unpd/wpp/Publications/ Files/Key_Findings_WPP_2015.pdf [Accessed: 9th February 2017]).

Verplanken, B., Aarts, H., Moonen, A., 1998. Habit versus planned behaviour: a field experiment. Br. J. Soc. Psychol. 37, 111-128. http://dx.doi.org/10.1111/j.2044 8309.1998.tb01160.x.

Verplanken, B., Walker, I., Davis, A., Jurasek, M., 2008. Context change and travel mode choice: combining the habit discontinuity and self-activation hypotheses. J. Environ. Psychol. 28, 121-127. http://dx.doi.org/10.1016/j.jenvp.2007.10.005.

Winters, M., Voss, C., Ashe, M.C., Gutteridge, K., McKay, H., Sims-Gould, J., 2015. Where do they go and how do they get there? Older adults' travel behaviour in a highly walkable environment. Soc. Sci. Med. 133, 304-312. http://dx.doi.org/10.1016/j. socscimed.2014.07.006.

Wretstrand, A., Svensson, H., Fristedt, S., Falkmer, T., 2009. Older people and local public transit: mobility effects of accessibility improvements in Sweden. J. Transp. Land Use 2 (2), 49-65. http://dx.doi.org/10.5198/jtlu.v2i2.87.

Zeitler, E., Buys, L., Aird, R., Miller, E., 2012. Mobility and active ageing in suburban environments: findings from in-depth interviews and person-based GPS tracking. Curr. Gerontology Geriatrics Res. 2012, 1-10. http://dx.doi.org/10.1155/2012/ 257186. 